\title{
The United States as an Open Economy
}

\author{
Richard N. Cooper
}

I $t$ is widely recognized that the United States has become more integrated into the world economy than it was, say, twenty-five years ago. For reasons that $\mathrm{I}$ hope to make clear, the United States is also more heavily integrated into the world economy than it was in the 1920s, the last period of great foreign investment, or in the 1890 s as well, although in certain respects the United States was very open to foreign events a hundred years ago and indeed felt them, as when the Baring collapse in London set off the U.S. bank panic of 1890 .

\section{The Facts of Greater Openness of the U.S. Economy}

It has become commonplace to cite certain measures of openness today. For instance, 40 percent of U.S. cropland and one-sixth of workers in the manufacturing sector are engaged in production for export. One-third of the loans of the largest banks are to overseas borrowers, and half of the profits of the largest U.S. corporations come from their investments abroad-at least in some years.

These figures, while suggestive, do not really capture the full impact of the openness of the U.S. economy. It is necessary to differentiate among different kinds of dependence that may develop on the rest of the world. In particular, a distinction must be made between "vulnerability" and "sensibility" to events elsewhere impinging on the U.S. economy. This distinction has been made much of by political scientists. Vulnerability concerns the real harm that can be done to the U.S. economy-and possibly to U.S. securityby the loss of access to foreign supplies or foreign markets. Sensitivity has to do with the frequency with which outside developments call for responsive adjustments within the U.S. economy, albeit perhaps at low real cost.

Some idea of the first type of dependence is given in table 1-1, which shows the high and growing dependence of the United States on foreign 
Table 1-1

Net U.S. Imports of Key Materials as Shares of Apparent Consumption, 1960-83

\begin{tabular}{lcccc}
\hline & 1960 & 1970 & 1980 & 1983 \\
\hline Manganese & $89 \%$ & $95 \%$ & $98 \%$ & $99 \%$ \\
Bauxite & 74 & 88 & 94 & 96 \\
Cobalt & 66 & 98 & 93 & 96 \\
Platinum Group & 82 & 78 & 88 & 84 \\
Chromium & 85 & 89 & 91 & 77 \\
Nickel & 72 & 71 & 71 & 77 \\
Potassium & $-{ }^{a}$ & 42 & 65 & 75 \\
Tin & 82 & 81 & 79 & 72 \\
Zinc & 46 & 54 & 60 & 66 \\
Tungsten & 32 & 50 & 53 & 39 \\
\hline
\end{tabular}

Source: Statistical Abstract of the United States.

${ }^{\text {aNet exports. }}$

sources of supply for a number of key materials, sudden loss of which would be serious for the economy and possibly for security. For this reason, the United States maintains strategic stockpiles of most of these products for use in event of war, which is the contingency most likely to lead to a serious cutoff of those commodities for which sources of supply are diverse. Gradual diminution of supply of such materials, as reflected in rising relative prices, would not be especially critical to the United States economy, as the technical possibilities exist for substituting away from them. Tin provides an example. Improved recovery techniques, tin-saving tinning processes, and wholesale substitution away from tinplate (especially in beverage vessels) have gradually reduced the use of tin in the U.S. economy.

The major import dependence of which all Americans have become aware concerns oil. Table 1-2 shows a growing dependence since 1960 on imports of energy supplies, and especially of oil, which increased through the late 1970s, after U.S. domestic production peaked and went into slow decline while U.S. consumption continued to grow with GNP. The U.S. economy experienced two major oil price shocks in the period 1973-80, and has built up a strategic petroleum reserve of nearly 500 million barrels (against a target of 750 million barrels) to deal with another future major shortfall, whether or not it is associated with war.

These commodities may appear to be special cases, and indeed they are in the degree of import dependence and their essentiality. But the growing openness of the U.S. economy is more general. As newspapers constantly remind people these days, over 20 percent of automobiles and steel consumed in the United States are imported, as are 17 percent of apparel by value (the more 
Table 1-2

U.S. Energy and Petroleum, 1960-83

(quadrillion Btu)

\begin{tabular}{lrrrr}
\hline & 1960 & 1970 & 1980 & $1983^{\mathrm{a}}$ \\
\hline Primary energy & & & & \\
Domestic production & 41.4 & 62.0 & 64.7 & 61.0 \\
Exports & 1.5 & 2.7 & 3.7 & 3.7 \\
Consumption & 43.7 & 66.4 & 75.9 & 70.5 \\
Imports & 4.2 & 8.4 & 16.0 & 11.9 \\
$\quad$ (as a percentage of supply) & $(9.3)$ & $(12.2)$ & $(20.1)$ & $(16.9)$ \\
Petroleum and natural gas liquids & & & & \\
Domestic production & 16.4 & 22.9 & 20.6 & 20.5 \\
Consumption & 19.9 & 29.5 & 34.2 & 30.0 \\
Imports & 4.0 & 7.5 & 14.7 & 10.5 \\
$\quad$ (as a percentage of & & & & \\
$\quad$ consumption & $(20.1)$ & $(25.4)$ & $(43.0)$ & $(35.0)$ \\
\hline
\end{tabular}

Source: Statistical Abstract of the United States.

Note: One barrel of oil contains about 5.8 million Btu.

a Preliminary.

Table 1-3

U.S. Trade in Goods and Services as Shares of GNP, 1929-84

\begin{tabular}{ccc}
\hline & Exports & Imports \\
\hline 1929 & $6.8 \%$ & $5.7 \%$ \\
1940 & 5.4 & 3.6 \\
1950 & 4.9 & 4.2 \\
1960 & 5.5 & 4.6 \\
1970 & 6.4 & 6.0 \\
1980 & 12.9 & 12.0 \\
1984 & 9.9 & 11.7 \\
\hline
\end{tabular}

Source: Council of Economic Advisers, Economic Report of the President, and Economic Indicators (various issues).

frequently mentioned 33 percent refers to square yards), and by 1984 , an impressive 75 percent of shoes.

Table 1-3 shows the trend of total foreign trade in goods and services relative to U.S. GNP since 1929. The ratio of trade to output fell in the 1930 s, but has risen steadily since World War II; exports reached nearly 13 percent of GNP in 1980, before falling in recent years of world recession. Exports of merchandise grew from 9 percent of goods output in 1929 to 
17 percent in 1979 . Imports roughly tracked the path of exports until the past few years, when they grew sharply relative to exports.

But trade figures only partially capture the increased openness of the U.S. economy. It is necessary also to look at the ownership of production, at financial markets, and at the labor force.

Under the heading of assets, table 1-4 gives claims on the rest of the world by private residents of the United States (government claims are excluded here). Direct investment involves U.S. ownership of production facilities abroad, which rose from $\$ 12$ billion in 1950 to $\$ 215$ billion in 1980 when valued at acquisition cost; the current market valuation would be considerably higher. For purposes of comparison, U.S. nominal GNP grew by a factor of 9.2 between 1950 and 1980 , so the book value of U.S. direct investment abroad grew about twice as fast as U.S. GNP, and even faster if the investment were valued at current prices.

Foreign direct investment in the United States, shown under liabilities in table $1-4$, grew from $\$ 3.4$ billion to $\$ 83$ billion during this period, about one-third faster than U.S. direct investment abroad. By 1980, foreign owned firms accounted for 11 percent of depreciable assets, 7 percent of sales, and 6 percent of employment in all U.S. manufacturing. The foreign share of assets in manufacturing had increased by a factor of three since 1963.

As far as U.S. corporations were concerned, their majority-owned foreign affiliates accounted for 25 percent of their worldwide sales in 1977 (the year of a detailed census of U.S. investment overseas), and 21 percent for

\section{Table 1-4}

U.S. Private Claims on and Liabilities to Foreigners, 1950-80 (\$ billion)

\begin{tabular}{lrrr}
\hline & 1950 & 1965 & 1980 \\
\hline U.S. private assets abroad & 19.0 & 81 & 517 \\
Direct investment & 11.8 & 49 & 215 \\
Claims by banks & 1.3 & 12 & 204 \\
Other nonbank claims & 5.9 & 20 & 97 \\
$\quad$ Bonds & 3.2 & 10 & 43 \\
Stocks & 1.8 & 5 & 19 \\
U.S. liabilities to foreigners & & 59 & 501 \\
Direct investment & 17.6 & 9 & 83 \\
Liabilities reported by banks & 3.4 & 17 & 151 \\
U.S. government securities & 5.8 & 12 & 134 \\
Other liabilities & 3.0 & 21 & 132 \\
Bonds (exc. U.S. govt.) & 5.4 & 1 & 10 \\
Stocks & 0.2 & 15 & 65 \\
\hline
\end{tabular}

Source: U.S. Department of Commerce, Survey of Current Business (various issues).

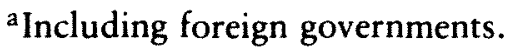


manufacturing firms alone. But U.S. firms had already invested heavily abroad by the mid-1960s, and the capital expenditure of U.S.-owned manufacturing firms overseas grew at roughly the same pace as their U.S. domestic capital expenditures from 1963-80, with foreign spending amounting in both years to about 21 percent of their worldwide capital spending. Since 1980 , their capital spending overseas has declined relative to their capital spending in the U.S. economy.

In terms of funding, U.S. nonfinancial corporations in 1980 drew 13 percent of their total domestic funds from abroad, up from 5 percent in the mid-1960s, involving both repatriated earnings on their foreign investments plus new foreign investment in the United States.

A comparable story can be told for financial assets. Table 1-4 also shows the growth in U.S. financial claims on foreigners plus foreign financial claims on the United States from 1950 to 1980 . Foreign financial claims on the United States have gone up over three times faster than U.S. GNP, and U.S. private financial claims on the rest of the world rose over four times more rapidly, from $\$ 7$ billion to $\$ 301$ billion, with the most rapid growth being claims by U.S. banks. Indeed, by the end of 1983, the 209 U.S. banks that do virtually all of the foreign bank lending had $\$ 357$ billion in claims on foreigners, compared with $\$ 1,126$ billion in total loans by all U.S. commercial banks.

Foreign banks operating in the United States accounted for 4.9 percent of bank assets and 9.5 percent of business loans in 1974; by 1983, they accounted for 14.6 percent of bank assets and 18.3 percent of business loans. Foreigners (including international organizations) held 16.3 percent of the U.S. government debt in the hands of the public at the end of 1983; this actually represented a decline from a peak of 24.8 percent in 1978 , but it was still up sharply from 6.4 percent in 1970 . Indeed, between 1970 and 1978, foreigners acquired no less than 40 percent of the increase in publicly held U.S. government debt.

Table 1-5 shows foreign ownership of selected categories of financial assets drawn from flow of funds statistics for 1966 and 1983. The figures suggest that foreign ownership of U.S. corporate and government securities more than trebled in relative importance between the mid-1960s and the present time.

What table 1-5 does not show is foreign ownership of U.S. currency, for this is unknown. But it is striking that of the roughly $\$ 169$ billion in U.S. currency in circulation at the end of 1984 , about $\$ 74$ billion was in the form of $\$ 100$ bills. Such bills represented 54 percent of the increase in currency in circulation between 1973 and 1984 . Where are all these $\$ 100$ bills? They show up only rarely in ordinary transactions. It is often alleged that this large denomination currency is tied up in the drug trade, but that can account for considerably less than half of the total. ${ }^{1}$ I conjecture that over $\$ 20$ billion in 
8 - How Open Is the U.S. Economy?

Table 1-5

Foreign Ownership of U.S. Financial Assets, 1966 and 1983

\begin{tabular}{lccc}
\hline & 1966 & 1983 & $\begin{array}{c}\text { Total Value } \\
1983 \\
\text { (\$trillion) }\end{array}$ \\
\hline Corporate stocks & $1.8 \%$ & $4.5 \%$ & $\$ 2.2$ \\
Corporate and foreign bonds & 1.5 & 7.9 & 0.6 \\
U.S. government securities & 3.8 & 14.1 & 1.2 \\
Open market paper & $2.4^{\mathrm{a}}$ & 14.4 & 0.3 \\
\hline
\end{tabular}

Source: Federal Reserve, Flow of Funds.

${ }^{a}$ Time and savings accounts.

U.S. currency, mostly $\$ 100$ bills, is abroad. U.S. currency is the legal currency in Panama and Liberia, two small countries, but it is widely used for transactions in Argentina-where Argentinian estimates place U.S. currency in circulation at over $\$ 5$ billion-and in Israel. It is also used extensively as a store of value throughout South America, the Arab countries, and indeed much of the rest of the world. The rapid growth of foreign holdings of $\$ 10 \mathrm{C}$ bills suggests that effective $M-1$ growth in the United States has been overstated during the past ten years.

Foreigners evidently traded their asset holdings more rapidly than did the typical American resident. In 1983, foreigners purchased about $\$ 70$ billion of U.S. corporate stock, representing about 7.5 percent of total gross stock purchases, compared with foreign ownership of less than 5 percent. This higher turnover rate is not new; foreigners accounted for 4.2 percent of gross purchases of U.S. corporate stock on all stock exchanges in 1963, compared with foreign ownership of less than 2 percent.

Population and the labor market also reflect an increased openness over the past quarter century. In 1980, there were 14.1 million foreign-born persons in the United States, 6 percent of the total population. The rate of legal immigration into the United States increased from 1.5 persons per 1,000 people in 1965 to 2.6 persons per 1,000 people in 1981 , both figures remaining well below the record 10.4 persons per 1,000 during the period $1901-10$. In addition to 597,000 legal immigrants in 1981, there were probably several hundred thousand illegal immigrants. Indeed it is probable that over 40 percent of annual increments to the labor force are now accounted for by immigrants.

Apart from immigrants, 11.8 million foreigners entered the United States in 1981 , compared with only 1.1 million in 1960 . Of the 11.8 million foreigners who entered, 1.1 million were on business, 272,000 were students, 65,000 were intracompany transfers of foreign personnel, and 81,000 were other traders or investors admitted to temporary residence (see table 1-6). 
Table 1-6

Foreign Visitors to the United States, 1960-81

(thousands)

\begin{tabular}{lcrr}
\hline & 1960 & 1970 & 1981 \\
\hline Immigrants admitted & 265 & 373 & 597 \\
Nonimmigrants admitted & 1,141 & 4,432 & 11,757 \\
$\quad$ Temporary visitors & 779 & 3,345 & 10,651 \\
$\quad$ For pleasure & n.a. & 3,020 & 9,515 \\
$\quad$ For business & n.a. & 325 & 1,135 \\
Treaty traders and investors & n.a. & 19 & 81 \\
Students & 35 & 107 & 272 \\
Intracompany transfers & n.a. & *a & 65 \\
\hline
\end{tabular}

Source: Statistical Abstract of the United States: Historical Statistics from Colonial Times to 1970.

a 400 individuals.

Table 1-7

U.S. Travelers to Overseas Destinations, $1960-80$ (thousands)

\begin{tabular}{lrrr}
\hline & 1960 & 1970 & 1980 \\
\hline Total & 1,634 & 5,260 & 8,163 \\
To Europe and Mediterranean & 832 & 2,829 & 3,934 \\
\hline
\end{tabular}

Source: U.S. Department of Commerce, Survey of Current Business (various issues).

Travel by Americans has also increased sharply, as shown in table 1-7. In 1980, 8.2 million Americans traveled abroad (excluding Canada and Mexico), up from 1.6 million in 1960.

This quick survey of data gives some impression of the increased openness of the U.S. economy over the past decade or three, depending on availability of the data. Roughly speaking, it suggests a doubling of the relative importance of foreign ownership or activity in the "real" side of the U.S. economy, and a trebling of the relative importance of foreign ownership or activity of foreigners in the financial side of the U.S. economy. In both instances, however, foreign ownership or activity, while growing rapidly, remains relatively small; the U.S. economy still looks relatively closed on this profile. That appearance is deceptive, however, as will be made clear.

It is of interest to compare the United States today with the Federal Republic of Germany, a large economy thought to be very open. Indeed, exports of goods and services account for over 30 percent of German GNP, and the FRG is dependent on imports for about half of its energy supply, both counts suggesting considerably greater openness than the United States offers. 
In financial markets, about 15 percent of German time deposits and money market paper are owned by foreigners, as are 8 percent of stocks and 4 percent of bonds. About 8 percent of long-term German bank loans are to foreigners. By these financial measures, the German economy is not markedly more open than the U.S. economy.

Before turning to the consequences and implications for policy of the increased openness of the U.S. economy, one should ask how it came about, and whether the tendency toward greater openness is likely to continue.

\section{Reasons for Increased Openness}

It is an oversimplification but nonetheless a basic truth to suggest that the increased openness of the U.S. economy, and indeed the greater openness of other countries along with the general growth of world economic interdependence, has occurred as a result of rapid technological developments in the fields of transportation and communication. The impact of these changes has been to reduce sharply the barriers to economic transactions imposed by geographic distance. These factors have been reinforced by reductions in tariff barriers to trade both in the United States and in the other major industrial countries. In 1900, the average U.S. tariff (weighted by import value) was 26 percent. By the 1950 s, this had fallen to 7 percent; by 1980 , it had fallen further to 3.5 percent. In 1900 , it cost 25 cents per word to send a telegraphic message from New York to major European capitals. The cost was hardly more than this in 1985-26.5 cents per word to London and 30.5 cents per word to Paris. Corrected for the twelvefold increase in the consumer price index that took place between 1900 and 1985, telegraphic communication cost in the latter year only 8-9 percent of what it had cost in 1900 .

The cost of international telephone messages fell even more sharply. A three-minute off-peak phone call between Washington and Frankfurt cost $\$ 12$ in 1950 , but only $\$ 2.76$ in 1985 , for a decline in real terms to only 5 percent of the cost 35 years earlier.

Comparable developments can be seen in the costs of air carriage. Table 1-8 shows the average revenue per passenger mile for U.S. domestic and international air traffic over the past fifty years. These figures represent the revenues from the service in question divided by the number of passenger miles traveled by paying passengers. The figures show a drop by two-thirds from 1940 to 1983 in the average fare for domestic travel, and a drop by fivesixths in the case of international travel. There was an even sharper decline for air freight. In 1983, international air freight cost an average of 37 cents per ton mile, about one-fourth in real terms of what it cost in 1950. (An aviation ton is a measure of volume, about 100 cubic feet.)

Of course, these average figures also reflect changes in the character of 
Table 1-8

Average Revenue for Air Travel, 1930-83

\begin{tabular}{|c|c|c|c|c|c|c|}
\hline & \multicolumn{4}{|c|}{ Passengers } & & \\
\hline & \multicolumn{2}{|c|}{ Domestic } & \multicolumn{2}{|c|}{ International } & \multicolumn{2}{|c|}{ International Freight } \\
\hline & Nominal & $\begin{array}{c}1985 \\
\text { dollars }^{\mathrm{a}}\end{array}$ & Nominal $^{\mathrm{a}}$ & $\begin{array}{c}1985 \\
\text { dollars }^{\mathrm{a}}\end{array}$ & Nominal & $\begin{array}{c}1985 \\
\text { dollars }\end{array}$ \\
\hline 1930 & 8.3 & 53.2 & n.a. & & n.a. & \\
\hline 1940 & 5.1 & 38.6 & 8.8 & 67.3 & $86^{\mathrm{C}}$ & $533^{c}$ \\
\hline 1950 & 5.6 & 24.6 & 7.3 & 32.1 & 36 & 158 \\
\hline 1960 & 6.1 & 21.9 & 6.3 & 22.9 & 31 & 111 \\
\hline 1970 & 6.0 & 16.5 & 5.0 & 13.8 & 21 & 56 \\
\hline 1980 & 11.5 & 14.9 & 8.8 & 11.4 & 32 & 42 \\
\hline 1983 & 12.1 & 13.0 & 9.8 & 10.5 & 32 & 34 \\
\hline
\end{tabular}

Sources: Civil Aeronautics Board, Reports to Congress, various issues; Federal Aviation Administration, Statistical Handbook of Aviation, various issues; and calculations from Statistical Abstract of the United States.

${ }^{a}$ Cents per revenue passenger-mile.

${ }^{b}$ Cents per revenue ton-mile.

c1943.

international travel as regards both the length of the trip and the class of service. Table 1-9 attempts to correct for that by citing fares between fixed points during the peak season. The first transoceanic commercial flight (a seaplane via Hawaii, Guam, and Manila) was from San Francisco to Hong Kong in August 1937. It was followed by the first commercial trans-Atlantic flight, from New York to Southampton and Marseilles (by seaplane via Bermuda, the Azores, and Lisbon). The round-trip fare across the Pacific in 1937 was $\$ 1,710$, or over $\$ 12,000$ in 1985 purchasing power. The roundtrip fare across the Atlantic two years later was $\$ 675$, or over $\$ 5,000$ in 1985 dollars. Fares are much more complicated today, with three classes of service, high-season and low-season fares, and excursion and advance-purchase fares. But if one takes high-season excursion or APEX fare as a point of comparison, the trans-Pacific fare today is only 8 percent of the 1937 fare in real terms, and the New York-London fare is only 12 percent of the 1939 fare in real terms. These comparisons neglect charter flights and People Express, which are cheaper still.

Lower fares are not the only improvements that have occurred. There have been dramatic reductions in the time required as well. The first transAtlantic cable was laid in 1867, making it possible for the first time to send a message between Europe and North America faster than a man could travel. Wireless made it possible to communicate with ships at sea and, later, with aircraft and spacecraft. The radio was still novel when the Titanic sank in 
12 - How Open Is the U.S. Economy?

Table 1-9

Round-Trip Air Fares, 1937-85

\begin{tabular}{|c|c|c|c|}
\hline & & Current $\$$ & $1985 \$$ \\
\hline \multicolumn{4}{|l|}{ Trans-Pacific } \\
\hline August 1937 & San Francisco-Hong Kong & 1,710 & 12,725 \\
\hline August 1939 & San Francisco-Hong Kong & 1,368 & 10,523 \\
\hline May 1949 & $\begin{array}{l}\text { San Francisco or } \\
\text { Los Angeles-Hong Kong } \\
\text { San Francisco or } \\
\text { Los Angeles-Tokyo }\end{array}$ & $\begin{array}{l}1,360.80 \\
1,170\end{array}$ & $\begin{array}{l}5,827 \\
5,244\end{array}$ \\
\hline January 1964 & Los Angeles-Tokyo & 783 & 2,697 \\
\hline January 1973 & Los Angeles-Tokyo & $773.80^{\mathrm{a}}$ & 1,860 \\
\hline August 1985 & $\begin{array}{l}\text { Los Angeles-Tokyo } \\
\text { San Francisco-Hong Kong }\end{array}$ & $\begin{array}{r}930^{\mathrm{b}} \\
1,094^{\mathrm{b}}\end{array}$ & $\begin{array}{r}930 \\
1,094\end{array}$ \\
\hline \multicolumn{4}{|l|}{ Trans-Atlantic } \\
\hline August 1939 & $\begin{array}{l}\text { New York-Southampton } \\
\text { New York-Marseilles }\end{array}$ & $\begin{array}{l}675 \\
675\end{array}$ & $\begin{array}{l}5,192 \\
5,192\end{array}$ \\
\hline May 1949 & $\begin{array}{l}\text { New York-London } \\
\text { New York-Paris }\end{array}$ & $\begin{array}{l}630 \\
666\end{array}$ & $\begin{array}{l}2,824 \\
2,985\end{array}$ \\
\hline January 1964 & $\begin{array}{l}\text { New York-London } \\
\text { New York-Paris }\end{array}$ & $\begin{array}{l}302.30 \\
391.80\end{array}$ & $\begin{array}{l}1,041 \\
1,350\end{array}$ \\
\hline January 1973 & $\begin{array}{l}\text { New York-London } \\
\text { New York-Paris }\end{array}$ & $\begin{array}{l}332^{\mathrm{c}} \\
344^{\mathrm{c}}\end{array}$ & $\begin{array}{l}798 \\
827\end{array}$ \\
\hline August 1985 & $\begin{array}{l}\text { New York-London } \\
\text { New York-Paris }\end{array}$ & $\begin{array}{l}645^{\mathrm{b}} \\
692^{\mathrm{d}}\end{array}$ & $\begin{array}{l}645 \\
692\end{array}$ \\
\hline
\end{tabular}

a14-21-day excursion. Full economy fare L.A.-Tokyo was \$911.40; New York-London, \$461-499.70, depending on season; New York-Paris, \$541.50.

b21-day advance purchase (APEX), high season. Full economy fare New York-London was $\$ 1,395$; L.A.-Tokyo, $\$ 1,410$.

c22-45-day peak period excursion. Peak period full economy fare New York-London was \$626; New York-Paris, \$676. Winter excursion rate New York-London was \$233, and off-peak full economy, \$456; New York-Paris, \$243 and \$480, respectively.

${ }^{\mathrm{d}}$ Excursion high season, 14-day minimum stay. Full economy fare was $\$ 1,604$.

1912. With modern practice, the 1,500 passengers who drowned would have been rescued. Unfortunately, the closest ship nearby had turned its radio receiver off before the Titanic sent its distress signal. But that signal permitted those in lifeboats to be rescued by a ship that traveled over fifty miles to the location of the disaster, a rescue that could not have occurred only five years before.

An English packet ship took five weeks to reach North America in the $1820 \mathrm{~s}$. By the $1870 \mathrm{~s}$, with steam vessels, steel hulls, and screw propellers, scheduled service between England and the United States took twelve days. By 1914, this had dropped to six days. Commercial air flights took about 18 hours in 1950, dropping to 8 hours with the introduction of commercial 
jet aircraft in 1958, and to 3.5 hours with the Concorde. Moreover, these improvements have occurred with a great saving of capital. A single Boeing 747 can move more people across the Atlantic in a season than the Queen Mary liner could.

The volume of transactions has responded to the reduction in costs. Table 1-6 has already shown that the number of foreigners visiting the United States grew from 1.1 million in 1960 to 11.8 million in 1981 . By 1983 , no less than one quarter of U.S. merchandise exports and nearly onesixth of U.S. imports were moved by air, up from negligible amounts in 1950. Commercial overseas telegraph messages (excluding leased lines) originating in the United States rose only slowly from 23 million messages in 1950 to 32 million messages in 1970, and then declined to 20 million messages in 1980, although the length of the average message increased sharply. International telephone calls originating in the United States, in contrast, rose enormously, from 700,000 in 1950 to 23 million in 1970, to 200 million in 1980 , and to 311 million in 1982 . The reason is the increase in the number of transoceanic telephone cable systems from 1 in 1950 to 18 in 1982; communications satellites increased from 1 in 1965 to 6 in 1982; and international direct dialing was introduced in the 1970s.

Both as a cause and as a consequence of these developments, foreign transactions are becoming more like domestic transactions. The foreignness is going out of international trade and financial relations, not so much because Americans are becoming more skillful at dealing with foreigners, as because foreigners are becoming more skillful and more accustomed to dealing with Americans. English has become the predominant language of international commerce, and differences in conventions of doing business are diminishing. Direct conversation and face-to-face meetings have always been the most effective way to close a business deal, with confirmation in writing (or by Telex), and in this respect the barriers of geographic distance have been greatly eroded by technology. With the advent of the commercial jet, it is possible to travel to Europe overnight, have a five-hour meeting, and return to the United States in time for supper after reporting in at the office. A comparable trip can take place originating in Europe. Close managerial supervision can thus be maintained over vast distances, and the changing nature of the modern corporation reflects that fact.

What of the future? The technological pipeline suggests further reductions in the cost of air transport and long-distance communication for at least another ten to fifteen years. Digitalization of voice communication and the introduction of fiber optic cables will enormously increase the capacity and reduce the cost of transoceanic communication. It is not absurd to think that by the year 2000, a given message can be sent to Europe for less than 10 percent of what it now costs in real terms. Much more efficient aircraft are also on the drawing boards (on both these points, see Keatley, 1985). So the 
barriers of distance will continue to decline rapidly, unless blocked by government action.

\section{Consequences of Greater Openness}

The greater openness of the U.S. economy was dramatically made evident to the American public by the world oil price increases of 1974 and 1979-80. Nixon's attempt to insulate the American public from price increases by price controls was only half successful, since only half of U:S. oil consumption was produced domestically; the world price had to be paid for the other half. The American public also became aware of the openness, albeit on a smaller scale, with the fivefold increase in sugar prices in 1973-74 as a result of a world sugar shortage. By the same token the world grain shortage of 1972-73 was a bonanza to U.S. farmers although a cost to U.S. consumers. Less evident than these price shocks but nonetheless important were the benefits that flowed to American consumers following the leveling off of U.S. oil production and from the rapid growth of imports of oil supplied by increased OPEC output from 1968 to 1977.

More recently economists have seen confidence in the major U.S. banks shaken by their heavy exposure to foreign debt combined, since late 1982, with an inability of debtors to pay their obligations on schedule. There has been a noticeable deterioration in the value of bank shares, correlated with the extent of overseas debt. ${ }^{2}$ Moreover, withdrawal of foreign funds from Continental Illinois, following difficulty with some of its domestic loans, greatly weakened that bank and led the Federal Reserve to lend it over \$2 billion during a period of adjustment.

The openness of the U.S. economy has permitted a much sharper drop in U.S. inflation rates than otherwise would have occurred since 1981. This drop was facilitated by a sharp appreciation of the dollar relative to other foreign currencies, which in turn was due in large measure to tight monetary policy in the United States, followed by expansionist fiscal policy since late 1981. Import prices (as measured by their GNP deflator) declined by 14 percent between 1981 and the first quarter of 1985, compared with an increase ranging from 10 to 25 percent in the deflators for sectors of the economy that are not exposed to foreign trade, such as housing, defense spending, and most services. The rise in the dollar put competitive pressure on the entire tradable sector, both export industries and those that compete with imports. Indeed, a sectoral analysis of price movements in the period since 1980 shows a striking downward impact arising from increased foreign competition on those sectors that are exposed to such competition, compared with sectors that are not (see S. Marris, 1986, chapter 2).

Furthermore, increased foreign competition has put special pressure on 
those sectors (notably autos and steel) where U.S. wages had gotten out of line with the general wage level. The early practice of "give-backs" was concentrated in those sectors subject to heavy foreign competition or to deregulation, although by $1984-85$, such wage adjustments had spread to other sectors as well, as employers were emboldened and unions were weakened by the increasingly competitive environment brought on partly by foreign trade, partly by deregulation, and partly by high unemployment (see D. Mitchell, 1985). Dornbusch and Fischer (1984) have estimated that a 10-percent average dollar appreciation lowers the consumption deflator by 2.1 percent, partly through its direct impact on prices of imports and import-competing goods, and partly indirectly through the exercise of wage restraint, with a mean lag of just under three quarters for the direct effect on prices and a lag of four quarters for the indirect effect through wages (see Dornbusch-Fischer, table 10).

The same forces have also helped to depress farm income. The stronger dollar has led to weaker dollar prices of all commodities sold into the world market, putting American farmers, whose debt is in dollars and whose costs have not declined proportionately, into a bind not unlike the developing countries that export primary products and whose debt is largely in dollars.

Another consequence of enlarged openness is to mitigate-indeed on some measures to eliminate entirely - the crowding out of private investment that many economists and others predicted would flow from the growth in the U.S. structural budget deficit since 1981. Instead, tight monetary and expansionist fiscal policies pulled foreign funds into the United States, to the historically unprecedented amount of 2.6 percent of GNP in 1984 . The net inflow of funds kept U.S. interest rates lower than they otherwise would have been, and imports filled what otherwise would have been a real resource gap, although the appreciation of the currency probably also inhibited the recovery of U.S. domestic output.

Finally, world debt problems combined with weak economic performance elsewhere in the world have hurt badly those sectors of the U.S. economy-such as heavy construction machinery-that have become dependent on worldwide investment for their sales.

\section{Implications of Increased Openness and Higher International Mobility}

At the outset of this chapter I drew attention to the distinction between "vulnerability interdependence" and "sensititivity interdependence," a distinction made by and useful to political scientists. An analogous distinction should be made by economists, with a somewhat different orientation, between the openness of a national economy and the international mobility of goods, 
services, and factors of production. A country can be highly open, as demonstrated by Japan's dependence on imported energy, yet still have low responsiveness to the emergence of small incentives to move capital, goods, or labor across national boundaries. Many of the factors just discussed have led both to greater openness and to greater sensitivity of the U.S. economy to events abroad. Other developments, such as gradual resource exhaustion, have led to greater openness, but by the same token to less sensitivity because the substitution possibilities from domestic production have been reduced. Each has its own set of implications for private and public economic decision making.

Greater openness leads to a larger impact of disturbances to the economy emanating from abroad, such as the oil and the sugar shocks already mentioned. On the other hand, it also leads to greater dissipation of disturbances that are domestic in origin, as the rest of the world acts as a kind of sink into which surplus production can be poured, or a source from which excess demand can be supplied. This phenomenon was first noticed by Americans in 1959, when a steel strike closed down U.S. steel production for much of the year, but a surge of steel imports diminished substantially the impact of the strike on the U.S. economy. Growing imports of oil and other raw materials as U.S. resources have been depleted have already been mentioned in the same connection.

The more rapid dissipation of disturbances originating in the domestic economy also applies to changes in domestic macroeconomic policy. If Americans spend more on imports out of each additional dollar of income received, then fiscal actions designed to stimulate the U.S. economy by increasing after-tax income in the hands of Americans will leak abroad more rapidly, reducing the fiscal impact on the U.S. economy (but not in general reducing its global impact). In the early 1960s, economists generally assumed a fiscal multiplier for the United States in the range of 2-2.5; that is, every milliondollar increase in government spending would increase GNP by $\$ 2-2.5$ million. More recently, the generally accepted multiplier is in the range of $1.5-2$, even before allowing for the effects of flexible exchange rates, which are discussed later. The lower multiplier implies a smaller impact of a given fiscal policy action today than was the case some years ago. ${ }^{3}$

A similar story can be told for monetary policy. Under a system of fixed exchange rates, with integrated capital markets, any attempt by a country to deviate from the world norm in monetary policy will simply evoke large movements of capital. The money supply becomes endogenous as a result of the commitment to fix the exchange rate, and even short-run deviations from the world norm become impossible if a country's money market is merely a part of a larger world money market.

The United States stands out as a partial exception to this extreme loss of monetary autonomy. The United States is so large a part of the world 
economy, and the dollar is so widely used, that the United States can influence world monetary conditions to the point of determining them. For this reason, other countries must accept U.S. leadership in the monetary arena under a regime of fixed exchange rates. It was their ultimate unwillingness to accept U.S. leadership that led to the breakdown of the exchange rate features of the Bretton Woods system in 1970-73. First Canada, then Britain, then Europe and Japan set their currencies free from the dollar in order to restore some monetary autonomy. The result is the present system of flexible exchange rates. It is noteworthy, however, that most countries in fact still fix their currencies to something-to the U.S. dollar, to the French franc, to some combination of currencies, and in the case of the eight currencies in the European monetary system, to each other. Thus relatively few currencies literally float freely, but they happen to be important ones-including the U.S. dollar, the Canadian dollar, the Japanese yen, and the British pound.

Flexible rates have indeed restored some monetary autonomy, as table 1-10 indicates. The correlation in movements between British and U.S. short-term interest rates rose sharply from the pre-World War I period to the interwar period, when London and New York rates were widely considered to have been closely integrated. Differences between the interest rates dropped sharply, and rates tended to move together. The correlation dropped and the average difference increased during the post-World War II period, represented in table $1-10$ by the years 1964-71. Both Britain and the United States maintained some restraints on outward capital movements

Table 1-10

Measures of New York-London Money Market Linkages: Short-Term Interest Rates, 1876-1984

(percentage points)

\begin{tabular}{lccc}
\hline & $\begin{array}{c}\text { Correlation } \\
\text { Coefficient }\end{array}$ & $\begin{array}{c}\text { Average } \\
\text { Difference }\end{array}$ & $\begin{array}{c}\text { Standard Deviation } \\
\text { of Difference }\end{array}$ \\
\hline $1876-1914^{\mathrm{a}}$ & .45 & 2.17 & 1.21 \\
$1925-38^{\mathrm{a}}$ & .93 & 0.24 & 0.71 \\
$1964-71^{\mathrm{b}}$ & .79 & 1.33 & 0.72 \\
$1974-84^{\mathrm{b}}$ & .55 & 2.23 & 2.67 \\
$1974-84^{\mathrm{c}}$ & .99 & .63 & .60 \\
\hline
\end{tabular}

Sources: Compiled from R. Dornbusch and S. Fischer, "The Open Economy: Implications for Monetary and Fiscal Policy," National Bureau of Economic Research Working Paper no. 1422, August 1984; and author's calculations.

${ }^{a}$ For 1876-1938, New York commercial paper rate and London private discount rate, monthly data from Morgenstern.

bFor 1964-84, Treasury bill rates from International Financial Statistics, monthly averages.

' For 1974-84, 90-day Eurodollar deposit rate and U.S. CD rate, from DRI monthly averages. 
during this period. Flexible exchange rates prevailed during the most recent decade, whereupon the correlation between British and U.S. interest rates dropped markedly and the average difference between them increased sharply. As expected, this was a function wholly of differences in the currency of denomination. The correlation between movements in interest rates on dollar-denominated claims in London and in New York was extremely high during this period, the average difference in interest rates was markedly lower than in the preceding decade, and the standard deviation of the difference was no greater than the difference itself. The coefficient of variation (the standard deviation of the difference divided by the mean difference) on dollar-denominated claims dropped to one-third of that prevailing between New York dollar securities and London pound-denominated claims during the period 1925-38. In comparing the average difference in interest rates in the 1925-38 period with the average difference in the most recent period, it is worth recalling that interest rates were very much lower in the former period, actually averaging below 1 percent during 1931-38, in contrast to short-term interest rates that ran from 5 to 16 percent in the most recent decade. So the average difference between interest rates as a fraction of the interest rates themselves was much smaller for dollar-denominated securities in the period 1974-84 than in 1925-38.

Flexible exchange rates have not only permitted greater national autonomy in the pursuit of monetary policy; they have also altered the way in which both monetary and fiscal policy work. Consider fiscal policy first, holding the money supply constant. An expansionist fiscal action will raise interest rates and induce a desire in foreigners to invest more in the country in question, while the attempted capital inflow will lead to an appreciation of the country's currency. That in turn will worsen the trade balance and hence weaken the influence of the expansionist fiscal action on the economy, an effect that augments the weakening that has already arisen from greater openness just noted. Taking these induced exchange rate effects of fiscal action into account may lead to a multiplier for the United States that is less than unity. ${ }^{4}$

Monetary policy used to operate on domestic economic activity primarily through two channels. Changes in monetary policy would raise or lower interest rates, and this in turn would discourage or encourage purchases for inventory, plant and equipment expenditure, and new housing construction. In addition, changes in monetary policy would alter the total wealth privately held through their influence on the prices of stocks and bonds; alterations in total wealth in turn affect current rates of spending in the same direction as the first effect. The second of these two effects was pervasive; the first was focused on interest-sensitive expenditures, most notably, in the United States, housing.

Under flexible exchange rates, a third impact of alterations in monetary 
ılicy must be allowed for: the impact on the exchange rate. Tighter moneary policy will lead to a currency appreciation, and that in turn will lead to ubstitution of foreign for domestic goods, thereby reducing the demand for lomestic production. In this case, unlike the first two channels, total spendng is not reduced, but spending on domestic output is reduced via substituion of foreign goods. This development is not necessarily undesirable. It preads the impact of changes in monetary policy more widely throughout he economy, with smaller effects on particular sectors. But Americans are lot yet accustomed to this effect of monetary action, and they identify ncreased foreign competition with particular actions or practices taken by oreign governments-often practices that have prevailed for many years and hat they are inclined to call "unfair" because they differ from practices that revail in the United States. There is no doubt some justification in some of he complaints along these lines. But most of the complaints should be lirected, not at foreigners, but to the fiscal and monetary authorities of the Jnited States, whose combined actions are in fact responsible for most of the ncreased foreign competition in the U.S. economy today-effects which, it ihould be recalled, were brought about deliberately as a way to combat inflaion.

Adjustment to these new conditions and channels by which monetary ?olicy works has lagged not only in American perception but also in U.S. aws and administrative practices. Under section 201 of the Trade Act of 1974 , any firm can appeal for import relief if its industry has been substanially injured by an increase in imports. (The provision long prevailing in the U.S. law that the increase in imports must be due to tariff reductions negotiated by the United States was dropped in 1974.) Thus the United States zurrently faces the anomalous situation in which the Federal Reserve may tighten money to combat inflation, thereby appreciating the U.S. dollar relative to other currencies and encouraging greater import competition, thereby triggering legally justifiable complaints by U.S. industries and permitting temporary import protection in order to diminish the resulting injury. (The president has the authority to reject recommendations by the International Trade Commission for temporary import relief, but he must justify to Congress his reasons for doing so, and he can be overridden by Congress.) Thus under flexible exchange rates there exists an unintended impact on microeconomic policy arising from macroeconomic actions.

In summary, an open economy under flexible exchange rates behaves very differently from a relatively closed economy under fixed exchange rates. (1) Monetary contraction operates directly on the price level by appreciating the currency as well as indirectly by depressing aggregate demand, so that the short-run Phillips curve is steepened. (2) Fiscal expansion will be less inflationary for the same reason, namely higher interest rates will lead to appreciation of the currency in the short run, but by the same token a given fiscal 
action will stimulate aggregate output less. How the impact of movements in the exchange rate, and expected future movements in the rate, following either of these kinds of actions, will influence domestic investment, and hence aggregate demand and output, is still an unresolved but important empirical question.

Just as flexible exchange rates have altered the channels by which monetary measures influence the U.S. economy, they also have altered the nature of the transmission of policy actions to other countries. Tight money in the United States, which under fixed exchange rates would have led to tight money in other countries as well, is not necessarily contractionary for others under flexible exchange rates. While it can put upward pressure on foreign interest rates, it also leads to a depreciation of currencies seen from the perspective of other countries, and hence improves the international competitiveness of their products. So contractionary monetary policy in the United States may on balance be expansionary for other countries.

Increased openness of the U.S. economy also casts further doubt on the already weak rationale underlying the universally used demand for money equation $M / P=F(Y, r)$. The only argument in the equation that is not brought into question by greater openness is the interest rate, $r$. How is $M$ to be defined when dollar-denominated bank accounts running several hundred billion dollars exist outside the United States, held by U.S. residents as well as nonresidents, when nonresidents hold substantial time deposits in the United States, and when even a substantial fraction-perhaps one-seventh-of U.S. currency is held abroad? Should the price level pertain to domestic output or domestic expenditure? That is, how much weight should be given to exchange rate movements? Does demand for money, however defined, depend on output, expenditure, or some combination of the two? Such questions can be ignored for a relatively closed economy. They should not be ignored for an open one.

\section{The Implications of Greater Mobility}

Higher international mobility has implications for all economic agents, especially for business firms. They can now think about marketing strategy not only in the home market, but in a worldwide market, as many do. They must worry about competition not only from domestic competitors, actual or potential, but also from foreign ones. Strategic decisions of oligopolist industries must be made on a global basis, not merely on a national basis, if the oligopolist position is to be preserved. This strategic thinking applies not only to product competition and marketing, but also to the location of production, since the combination of transport costs and actual or potential import barriers may exceed the disadvantages of buying or building and managing a 
plant at long distance. Labor unions too must take an international view if they want to preserve a superior relative position for their members.

But the same improved mobility that in today's world influences business investment and marketing decisions also makes business more sensitive and hence more responsive to differences in national policies with respect to regulation and to taxation. Higher mobility leads to a generalization of arbitrage-a tendency to equalize conditions worldwide. Outflows of technology and capital raise productivity and incomes abroad toward levels in the originating countries. Inflows of labor put downward pressure on wages in the country of immigration. Arbitrage also leads to convergence of national regulation and taxation. Tax havens, most notably Switzerland, have existed for many decades, permitting firms to run their international transactions through trading companies whose profits are taxed at much lower rates than they are taxed either in the country of production or in the country of final sale. Appropriate adjustment of intracorporate prices permits maximization of after-tax profits.

More recently regulatory havens have also sprung up: first Luxembourg in banking and security issues, then the Bahamas, Cayman, and other offshore banking centers. As long as these havens remain relatively small, they co-exist with normal flows of trade and finance and with historic regulation and taxation. But when they exceed a certain size, they put pressure on the regulatory or tax environment everywhere. The growing use by U.S. corporations of the Netherlands Antilles for raising funds abroad on which interest payments were not subject to withholding tax at source (under the terms of a U.S.-Netherlands tax treaty) put such pressure on U.S. tax revenues from this source that the U.S. Treasury persuaded Congress in 1984 to remove the withholding tax altogether on interest payments to foreigners. France and Germany promptly followed suit, and Japan is actively discussing a similar change. The growth of nameplate banking facilities in Grand Cayman, the Bahamas, and Bermuda (whereby bank deposits could avoid the reserve requirements and interest rate limitations imposed on bank deposits in the United States) and disputes over state taxation of such activity, led in 1981 to the creation of international banking facilities (IBFs) in the United States. IBFs are generally exempt from these regulations subject to certain restrictions on the type of transactions that they can undertake. ${ }^{5}$

The responsiveness of internationally mobile firms has led some countries-and governmental jurisdictions within countries-to take advantage of this mobility by creating a favorable environment for these firms in order to generate local income and employment. Thus the cities and states within the United States compete with one another and with Canadian provinces for the location of major new factories. Not so long ago the province of Ontario and the state of Ohio were locked in a competition of favors for the location of a new automobile engine factory. Smaller countries such as Ireland and Singa- 
pore have also competed vigorously for internationally mobile firms by offer. ing land and by creating an especially favorable tax or regulatory environ. ment; and as already discussed, even the United States has responded to this competition in limited areas such as allowing international banking facilities: removing the withholding tax on interest payments to foreigners, and permitting states to compete for new firms through the flotation of tax-exempt development bonds.

Accommodation to this competitive environment in policy is only one response. The United States has also from time to time engaged in aggressive action to extend its regulatory or tax jurisdiction to residents in other countries. Thus the Securities and Exchange Commission (SEC) has served disclosure requirements on foreign firms whose securities are traded (without the approval of the firms) in the U.S. over-the-counter market. The United States government or courts have often subpoenaed information abroad pertaining to enforcement of U.S. tax or antitrust laws. And of course there was the recent celebrated conflict between the United States and several European countries over their ability to sell the Soviet Union gas turbines made abroad under U.S. license, in alleged violation of U.S. export control laws. This extraterritorial extension of U.S. laws has led in turn to blocking legislation by several other countries, including Britain, France, and Germany, whereby firms located in those countries, regardless of ownership, are prohibited from complying with government or court orders emanating from another country (meaning mainly the United States). Such laws of course put firms in a direct conflict of jurisdictions, whereby they cannot avoid violating the laws or injunctions of one country or another. ${ }^{6}$ This kind of situation is obviously unsustainable in the long run, and it suggests the need for cooperation agreements between countries concerning the enforcement of regulations and taxation. Indeed, such agreements have been reached with Australia and Canada with respect to the collection of information pertaining to antitrust enforcement, and ad hoc cooperative arrangements have been established with Germany. ${ }^{7}$ But the necessity for cooperation with other countries also implies a mutual accommodation of national policies into a common framework, and a corresponding loss of autonomy. The problem arises because of greater international mobility, and it will become more acute over time as international mobility increases even further due to technological improvements in travel and communication.

\section{Notes}

1. It is estimated that the U.S. drug trade runs about $\$ 110$ billion a year. If one applies the average M1 velocity of 6.7 to the drug trade and assume that only $\$ 100$ bills are used for transactions, that would account for only about one-fifth of the $\$ 100$ 
bills in circulation. Even if transactions velocity were only half of what it is for M1 with respect to GNP, only $\$ 33$ billion of the $\$ 100$ bills would be accounted for.

2. According to calculations by S. Kyle (1985), by late 1983, the market value of bank shares suggested a discount of 22 percent on Latin American debt in each bank's portfolio:

3. Ideally, it would be possible to compare the multipliers estimated in the various large-scale macroeconomic models developed for the U.S. economy over the last thirty years. Unfortunately, such a comparison is badly marred by the often radically different treatment given to other dimensions of economic policy (especially monetary policy) and to the greater complexity of models permitted by modern computational facilities, giving rise to much more complex compositional effects in recent models than was the case in earlier ones. The model of project LINK shows modestly higher multipliers for the United States, Canada, and Germany in the early 1970s than for the early 1960s, but lower multipliers for Britain, France, and Japan. See Helliwell and Padmore, 1985.

4. In open economy macroeconomic models that have become fashionable, incorporating the portfolio balance approach to international capital movements, fiscal expansion with money held unchanged must lead on impact to an appreciation of the currency. (See, for example, Obstfeld, 1985.) But a more eclectic approach to modeling capital movements leads to the result that a country's exchange rate could go either up or down depending on the nature of interest-sensitive capital mobility and the response of domestic interest rates to expansionist action. Indeed the more complex macroeconomic models more often than not yield the result that fiscal expansion will lead to depreciation of the currency for countries other than the United States. Under these circumstances, of course, the fiscal multiplier is augmented rather than diminished.

5. For a description of the origin and early creation of IBFs, see Sydney Key, 1984.

6. Two recent tax cases involve Marc Rich (whose firm agreed to turn over certain documents to U.S. prosecutors, only to have them confiscated by Swiss authorities who charged that their delivery would violate Swiss secrecy laws) and the Italian firm of Gucci, which found itself charged with contempt of court by a U.S. court for not delivering documents which a Hong Kong court had enjoined it from delivering. See International Herald Tribune, August 17-18, 1985, pp. 9, 12. In a similar vein, squabbles over jurisdiction of liability with respect to the Union Carbide-Bhopal plant disaster will very likely continue for years.

7. On the international legal aspects of antitrust enforcement, see Atwood and Brewster, 1981. Of course, openness of the economy raises questions about the value of traditional antitrust criteria, such as concentration indexes. An open economy may have only one firm producing at home and still enjoy the advantages of competition due to actual or potential sales by foreign producers.

\section{References}

Atwood, James, and Kingman Brewster, Jr., Antitrust and American Business Abroad, 2nd edition, New York: McGraw-Hill (1981). 
Dornbusch, Rudiger, and Stanley Fischer, "The Open Economy: Implications for Monetary and Fiscal Policy," National Bureau of Economic Research, Working Paper No. 1422 (August 1984).

Helliwell, John, and Timothy Padmore, "Empirical Studies of Macroeconomic Interdependence" in Ronald W. Jones and Peter B. Kenen (eds.), Handbook in International Economics, vol. 2, Amsterdam: Elsevier Science Publishers (1985).

Keohane, Robert O., and Joseph S. Nye, Jr., Power and Interdependence: World Politics in Transition, Boston: Little Brown (1977).

Keatley, Anne G., ed., Technological Frontiers and Foreign Relations, Washington: National Academy of Sciences (1985).

Key, Sydney, "International Banking Facilities as a Free Economic Zone," Aussenwirtschaft vol. 39, 1984, pp. 57-74.

Kyle, Steve, unpublished Ph.D. dissertation, Department of Economics, Harvard University (1985).

Marris, Stephen, Deficits and the Dollar: The World Economy at Risk, Washington: Institute for International Economics (1986).

Mitchell, Daniel B., "Shifting Norms in Wage Determination," Brookings Papers on Economic Activity, No. 2, 1985, pp. 575-99.

Morganstern, Oskar, International Financial Transactions and Business Cycles, Princeton, N.J.: Princeton University Press (1959).

Obstfeld, Maurice, "Floating Exchange Rates: Performance and Prospects," Brookings Papers on Economic Activity, No. 2, 1985, pp. 369-450. 